\title{
The Power Characteristics of the Reversible Radial Crowns with Disk Tools for Roadheaders of Selective Action
}

\author{
Mametyev Leonid E. ${ }^{\mathrm{a}}$, Khoreshok Aleksey A. ${ }^{\mathrm{b}}$, Tsekhin Alexander M. ${ }^{\mathrm{c}}$, Mukhortikov Sergey G. ${ }^{\mathrm{d}}$, Borisov Andrey Yu. ${ }^{\mathrm{e}}$ \\ T. F. Gorbachev Kuzbass State Technical University \\ Kemerovo, Russian Federation \\ a,c,d,e bau.asp@rambler.ru; bhaa.omit@kuzstu.ru
}

\begin{abstract}
The areas of improvement in the design of the crowns of roadheaders of selective action and other mining machines. Suggested was the usage of biconical, conical disk tools and their attachment assemblies to the triangular prisms on the crowns of roadheaders and shearers-bladed screws for the destruction of structurally inhomogeneous working faces. The solution to the problem of combining the processes of rock destruction, crushing and loading by boom-type cutting bodies in driving headings by roadheaders of selective action is presented. The recommendations are given on agreed reverse modes of two radial crowns with the disc tool mounted on triangular prisms for the extension of loading area in the near-sidewalls spaces of mine workings. The process of formation of loads on the disc tool during destruction of rock was studied. The calculated dependences are presented of the transverse efforts on the cutting body with two kinematiccally connected radial reversible crowns for eight standard fixed stages of rotation of the crowns with the disc tools in the destruction.
\end{abstract}

Keywords - roadheader, effector, crown, triangular prism, disc tool, reverse, displacement, rock face, contact strength, effort, moment.

\section{INTRODUCTION}

Currently the fleet of roadheading machines at coal mines in Kuzbass basically consists of boom-type roadheaders of domestic and import production with the capacity of 1.7 to 2.8 $\mathrm{m} 3 / \mathrm{min}$ (at $\sigma_{\text {compr }}$ up to $30-40 \mathrm{MPa}$ ) and up to $0.15-0.35$ $\mathrm{m}^{3} / \mathrm{min}$ (at $\sigma_{\text {compr }}$ up to $80-120 \mathrm{MPa}$ ), and weight from 23 to $135 \mathrm{t}$. They are used for breaking and loading of rock mass with the index of abrasion (a) up to $15-18 \mathrm{mg}$ when driving horizontal and inclined (up to $12-18^{\circ}$ ) mine workings of arched, trapezoidal and rectangular shapes with the crosssectional area $(\mathrm{S}) 7$ to $38 \mathrm{~m}^{2}$. The fleet of roadheaders by country of production includes the following types: KP21, KP21-150, KP-200; KP220, KP200T, KPYU-50, SM130K (Russia); П110, П220, KSP-22, KSP-32(33), KSP-35, KSP42, KPL, KPD, KPA, KPU (Ukraine); M200, LH1500, MK2BP, MK5 (UK); MC 350, MR 520, MT 720, MB 600, MB 670 (Sweden); EBZ135, EBZ160, EBZ200, EBZ340 (China); T1.14, T1.24, T2.21, T2.24, T3.20, T4.31 (Germany). The analysis of the parameters of the cutting bodies of the roadheaders which have a significant effect on the processes of formation of the loads during destruction of rocks shows that they are in the following range: the engine power of the roadheader cutting bodies (N) from 75 to $400 \mathrm{~kW}$, crown rotation speed (n) from 23 to $65 \mathrm{~min}^{-1}$, diameter of crowns $\left(\mathrm{D}_{\mathrm{K}}\right)$ from 0.85 to $1.2 \mathrm{~m}$, the telescopic boom extension (lt) from 0.5 to $0.8 \mathrm{~m}$.

\section{SUBJECT OF RESEARCH}

The research conducted by the scientists of the department of mining machines and complexes of the Mining institute of the T.F. Gorbachev KuzSTU together with the employees of the company of "SUEK-Kuzbass" was focused on the development and identification of parameters of loading of two kinematically connected reverse radial crowns equipped with a disk tool [1-3]. Various processes and roadheading equipment were reviewed in publications [4-27] and can be useful in addressing several issues in designing of cutting bodies for roadheaders.

In the previous studies we studied the mechanisms of destruction of coals and rocks by the disk tools on screw-type cutting bodies of coal miners and on crowns of roadheaders with two-point attachment assemblies.

The present study is aimed at determining the stress-strain state and the total loads on double-crown cutting bodies with a disk tool on multi-faceted prisms in the presence of supporting brackets as attachment assemblies.

\section{RESULTS AND DISCUSSIONS}

In the process of driving a heading, two radial crowns 1 and 2 equipped with disc tools on triangular prisms (Fig. 1) can operate in the following modes: reverse rotation (n) of crowns; joint motion (V) of crowns from the bottom upwards (Fig. 1, a) and vice versa (Fig. 1, b). The formation of the external load was investigated for all the above-mentioned modes in a wide range of rocks from mudstone to hard sandstone with the contact strength of $\left(\mathrm{P}_{\mathrm{c}}\right) 150,230,350,490,700,860,1000,1250 \mathrm{MPa}$.

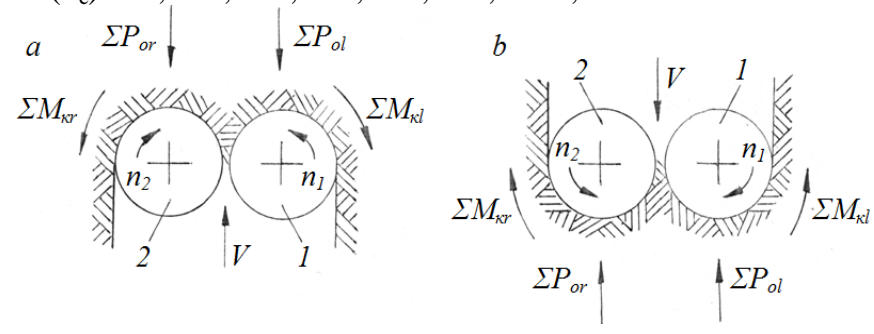

Fig. 1. Schematic of forces $\Sigma \mathrm{P}_{\mathrm{o}}$ and torques $\Sigma \mathrm{M}_{\mathrm{K}}$ in the plane of rotation of a two-crown cutting body: $a$ - at boom lifting; $b$ - at boom lowering 
The schemes of the set of tools on each crown form a double-threaded helix with two disc tools in the line of rolling and a pitch $\mathrm{t}$ between them of $75 \mathrm{~mm}$. The disc tools are installed on the crowns with a certain radius $\mathrm{R}$ : disc 1 $0.340 \mathrm{~m}$; disc $2-0.360 \mathrm{~m}$; disc $3-0.385 \mathrm{~m}$; disc 4- $0.41 \mathrm{~m}$; disc $5-0.43 \mathrm{~m}$; disc $6-0.45 \mathrm{~m}$; disc $7-0.475 \mathrm{~m}$; disk $8-$ $0.49 \mathrm{~m}$. During the calculations, the turning of the left crown was fixed at a certain angle in stages: stage $1-22.5^{\circ}$; stage $2-67.5^{\circ}$; stage $3-122.5^{\circ}$; stage $4-157.5^{\circ}$; stage $5-$ $202.5^{\circ}$; stage $6-247.5^{\circ}$; stage $7-292.5^{\circ}$; stage $8-337.5^{\circ}$. The turning of the right crown was also fixed in stages: stage $1-45^{\circ}$; stage $2-90^{\circ}$; stage $3-135^{\circ}$; stage $4-180^{\circ}$; stage $5-225^{\circ}$; stage $6-270^{\circ}$; stage $7-315^{\circ}$; stage $8-$ $360^{\circ}$.

In the interaction of the crown with the rock it experiences the external load as the total efforts $\Sigma \mathrm{P}_{\mathrm{or}}, \Sigma \mathrm{P}_{\mathrm{ol}}$ and total torques $\Sigma \mathrm{M}_{\mathrm{kr}}, \Sigma \mathrm{M}_{\mathrm{kl}}$ (Fig. 1).

It is suggested on the basis of research conducted by the authors to focus on the efforts as the most important component of external loads on the disk tool.

Effort $\Sigma \mathrm{P}_{\mathrm{o}}$ was determined from the expression:

$\sum \mathrm{P}_{\mathrm{o}}=\mathrm{P}_{\mathrm{o} 1}+\mathrm{P}_{\mathrm{o} 2}+\mathrm{P}_{\mathrm{o} 3}+\mathrm{P}_{\mathrm{o} 4}+\mathrm{P}_{\mathrm{o} 5}+\mathrm{P}_{\mathrm{o} 6}+\mathrm{P}_{\mathrm{o} 7}+\mathrm{P}_{\mathrm{o} 8}, \mathrm{kN}$ (1)

where $\mathrm{P}_{\mathrm{o} 1}-\mathrm{P}_{\mathrm{o} 8}$ projection of efforts on Y-axis (Fig. 2, 3, 4, 5) acting from the side of rock on disc tools nos. 1, 2, 3, 4, 5, 6, 7 , and 8 .

In Fig. 2, as an example, diagrams of the efforts on the disk tools no. $6,2,7,3,8,4,5,1$ of the first spiral of the left crown during its upward motion, and in Fig. 3 - on discs no. 5, 1, 8, 4, $7,3,6,2$ of the second spiral of the left crown during its downward motion. Fig. 4 shows a diagram of the efforts on the disk tools no. 5, 1, 8, 4, 7, 3, 6, 2 of the first spiral of the right crown during its upward motion, and in Fig. 5 - on discs no. 5 , $1,8,4,7,3,6,2$ of the second spiral of the right crown during its downward motion. Disc tools are mounted two on one beam: № 6 and № 2; № 7 and № 3; № 8 and № 4; № 5 and № 1 with different radius of rolling R. In the diagrams of Fig. 2-5 for the purpose of simplification the efforts are shown acting only on the outer disk tools. On the internal disk tools the layout is shown similarly using the coordinates of application of effort of rolling $\mathrm{Pz}$ and impressing effort $\mathrm{Py}$, whose direction coincides with the direction of the radius-vector of the triangular prism with a specific disk.

Components of the efforts of rolling $\mathrm{P}_{\mathrm{z}}$ and the effort of impressing $\mathrm{P}_{\mathrm{y}}$ in the coordinates of the points of application of resultant efforts in the contact area of disk tools 5, 8, 7 and 6 with the rock of the face were determined by the known methods described in the standard OST 12.44.25884. Mining combines. Selection of parameters and calculation of cutting and feeding forces on the cutting bodies.

As an example, Fig. 6 shows the dependences of the total axial effort $\Sigma \mathrm{P}_{\mathrm{o}}$ acting on all disk tools of the double-threaded left-hand crown of the cutting body during its one full clockwise turn with the upward motion.

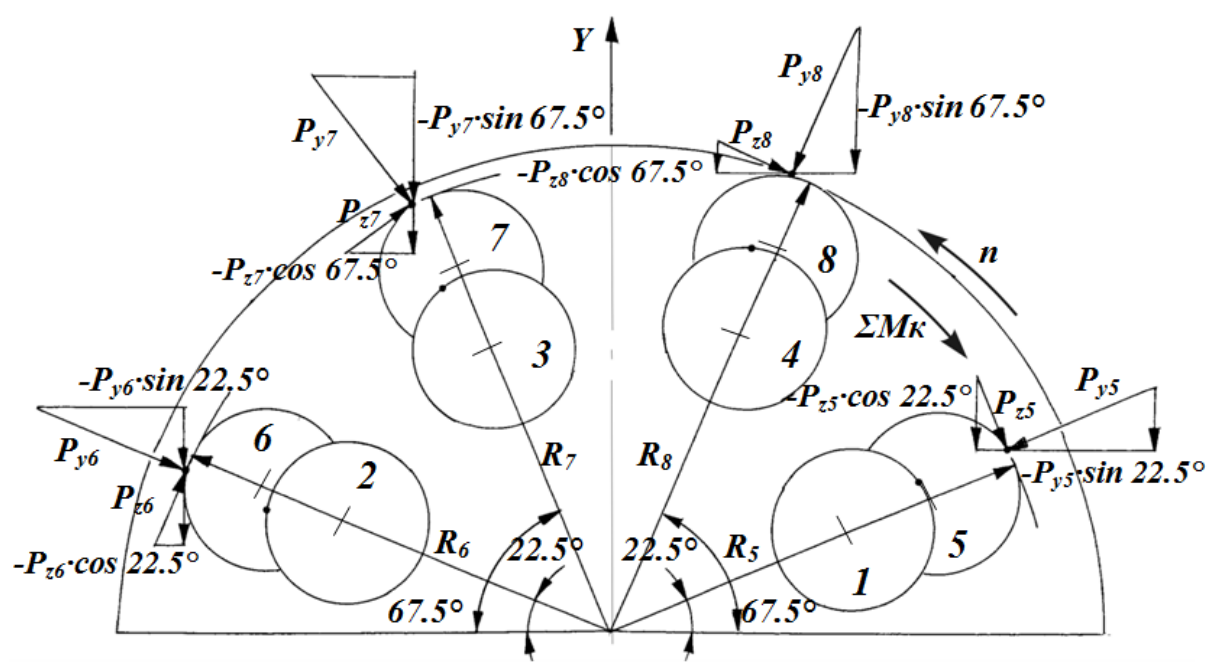

Fig. 2. The scheme of components of the rolling efforts $P_{z}$ and the effort of impressing $P_{y}$ in the destruction of rock in the face by disk tools (№ 6, 2, 7, 8, 5) of the left crown at its upward motion

The method was implemented with reference to the design scheme in Fig. 2 in the form of the following expressions included in the structure of formula (1):

$$
\begin{array}{ll}
\mathrm{P}_{\mathrm{o} 6}=-\mathrm{P}_{\mathrm{y} 6} \sin 22.5^{\circ}-\mathrm{P}_{\mathrm{z} 6} \cos 22.5^{\circ} ; & \mathrm{P}_{\mathrm{o} 7}=-\mathrm{P}_{\mathrm{y} 7} \sin 67.5^{\circ}-\mathrm{P}_{\mathrm{z} 7} \cos 67.5^{\circ} ; \\
\mathrm{P}_{\mathrm{o} 8}=-\mathrm{P}_{\mathrm{y} 8} \sin 67.5^{\circ}-\mathrm{P}_{\mathrm{z} 8} \cos 67.5^{\circ} ; & \mathrm{P}_{\mathrm{o} 5}=-\mathrm{P}_{\mathrm{y} 5} \sin 22.5^{\circ}-\mathrm{P}_{\mathrm{z} 5} \cos 22.5^{\circ} ; \\
\mathrm{P}_{\mathrm{o} 2}=-\mathrm{P}_{\mathrm{y} 2} \sin 22.5^{\circ}-\mathrm{P}_{\mathrm{z} 2} \cos 22.5^{\circ} ; & \mathrm{P}_{\mathrm{o} 3}=-\mathrm{P}_{\mathrm{y} 3} \sin 67.5^{\circ}-\mathrm{P}_{\mathrm{z} 3} \cos 67.5^{\circ} ; \\
\mathrm{P}_{\mathrm{o} 4}=-\mathrm{P}_{\mathrm{y} 4} \sin 67.5^{\circ}-\mathrm{P}_{\mathrm{z} 4} \cos 67.5^{\circ} ; & \mathrm{P}_{\mathrm{o} 1}=-\mathrm{P}_{\mathrm{y} 1} \sin 22.5^{\circ}-\mathrm{P}_{\mathrm{z} 1} \cos 22.5^{\circ}
\end{array}
$$




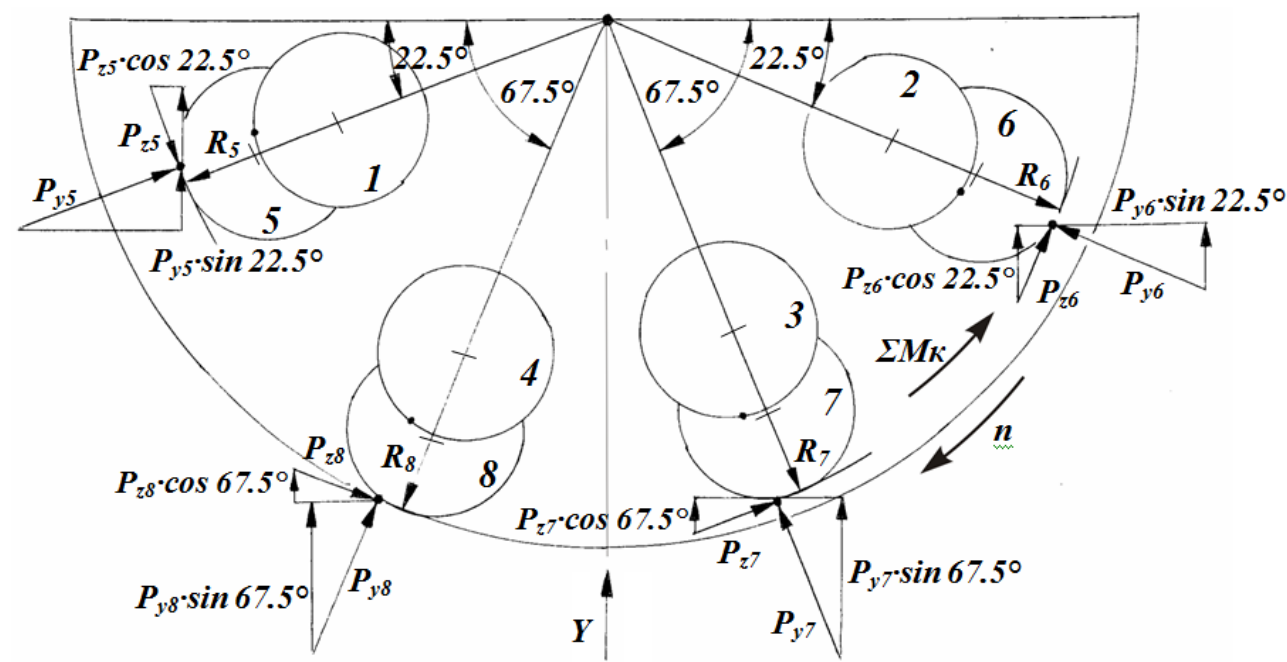

Fig. 3. The scheme of components of the efforts of rolling $P_{z}$ and the effort of impressing $P_{y}$ in the destruction of rock by disk tools (№ 5, 1, 8, 4, 7, 3, 6,2) of the left crown at its downward motion

For the scheme shown in Fig. 3 the following calculated expressions were received:

$$
\begin{array}{ll}
\mathrm{P}_{\mathrm{o} 5}=\mathrm{P}_{\mathrm{y} 5} \sin 22.5^{\circ}+\mathrm{P}_{\mathrm{z} 5} \cos 22.5^{\circ} ; & \mathrm{P}_{\mathrm{o} 8}=\mathrm{P}_{\mathrm{y} 8} \sin 67.5^{\circ}+\mathrm{P}_{\mathrm{z} 8} \cos 67.5^{\circ} ; \\
\mathrm{P}_{\mathrm{o} 7}=\mathrm{P}_{\mathrm{y} 7} \sin 67.5^{\circ}+\mathrm{P}_{\mathrm{z} 7} \cos 67.5^{\circ} ; & \mathrm{P}_{\mathrm{o} 6}=\mathrm{P}_{\mathrm{y} 6} \sin 22.5^{\circ}+\mathrm{P}_{\mathrm{z} 6} \cos 22.5^{\circ} ; \\
\mathrm{P}_{\mathrm{o} 1}=\mathrm{P}_{\mathrm{y} 1} \sin 22.5^{\circ}+\mathrm{P}_{\mathrm{z} 1} \cos 22.5^{\circ} ; & \mathrm{P}_{\mathrm{o} 4}=\mathrm{P}_{\mathrm{y} 4} \sin 67.5^{\circ}+\mathrm{P}_{\mathrm{z} 4} \cos 67.5^{\circ} ; \\
\mathrm{P}_{\mathrm{o} 3}=\mathrm{P}_{\mathrm{y} 3} \sin 67.5^{\circ}+\mathrm{P}_{\mathrm{z} 3} \cos 67.5^{\circ} ; & \mathrm{P}_{\mathrm{o} 2}=\mathrm{P}_{\mathrm{y} 2} \sin 22.5^{\circ}+\mathrm{P}_{\mathrm{z} 2} \cos 22.5^{\circ}
\end{array}
$$

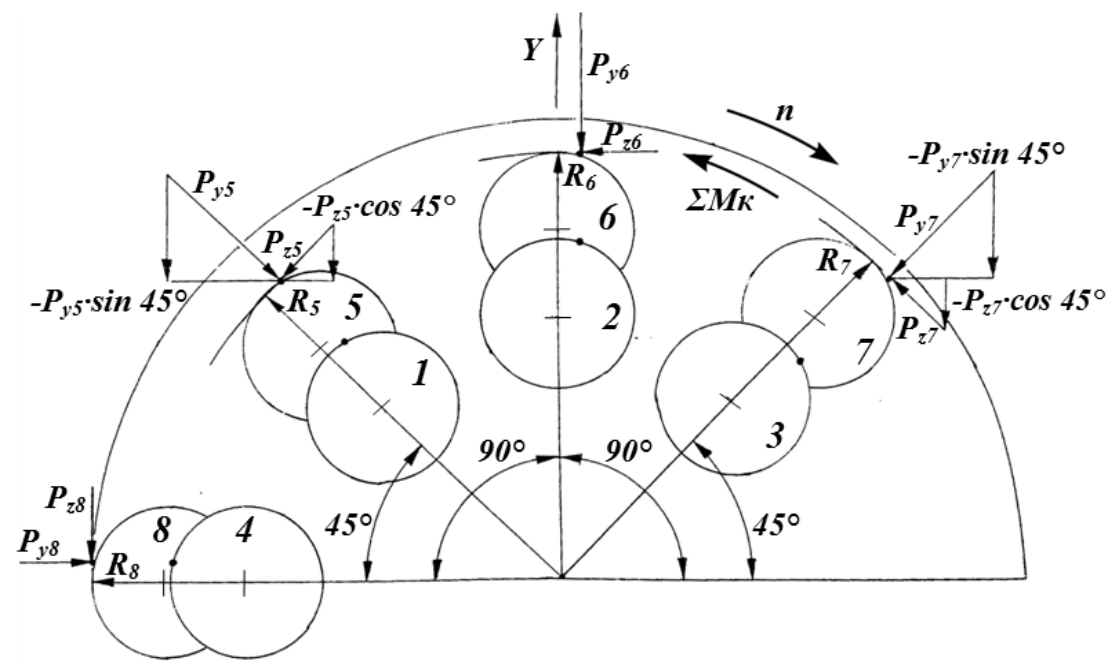

Fig. 4. The scheme of components of the efforts of rolling Pz and the effort of impressing Py in the destruction of rock by disk tools (№ 7, 3, 6, 2, 5, 1, 8, 4) of the right crown at its upward motion

For the option of the upward motion of the right crown presented in Fig. 4, the calculated expressions are as follows:

$$
\begin{aligned}
& \mathrm{P}_{\mathrm{o} 7}=-\mathrm{P}_{\mathrm{y} 7} \sin 45^{\circ}-\mathrm{P}_{\mathrm{z} 7} \cos 45^{\circ} ; \mathrm{P}_{\mathrm{o} 6}=-\mathrm{P}_{\mathrm{y} 6} ; \mathrm{P}_{\mathrm{o} 5}=-\mathrm{P}_{\mathrm{y} 5} \sin 45^{\circ}-\mathrm{P}_{\mathrm{z} 5} \cos 45^{\circ} ; \mathrm{P}_{\mathrm{o} 8}=-\mathrm{P}_{\mathrm{z} 8} ; \\
& \mathrm{P}_{\mathrm{o} 3}=-\mathrm{P}_{\mathrm{y} 3} \sin 45^{\circ}-\mathrm{P}_{\mathrm{z} 3} \cos 45^{\circ} ; \mathrm{P}_{\mathrm{o} 2}=-\mathrm{P}_{\mathrm{y} 2} ; \mathrm{P}_{\mathrm{o} 1}=-\mathrm{P}_{\mathrm{y} 1} \sin 45^{\circ}-\mathrm{P}_{\mathrm{z} 1} \cos 45^{\circ} ; \mathrm{P}_{\mathrm{o} 4}=-\mathrm{P}_{\mathrm{z} 4} .
\end{aligned}
$$




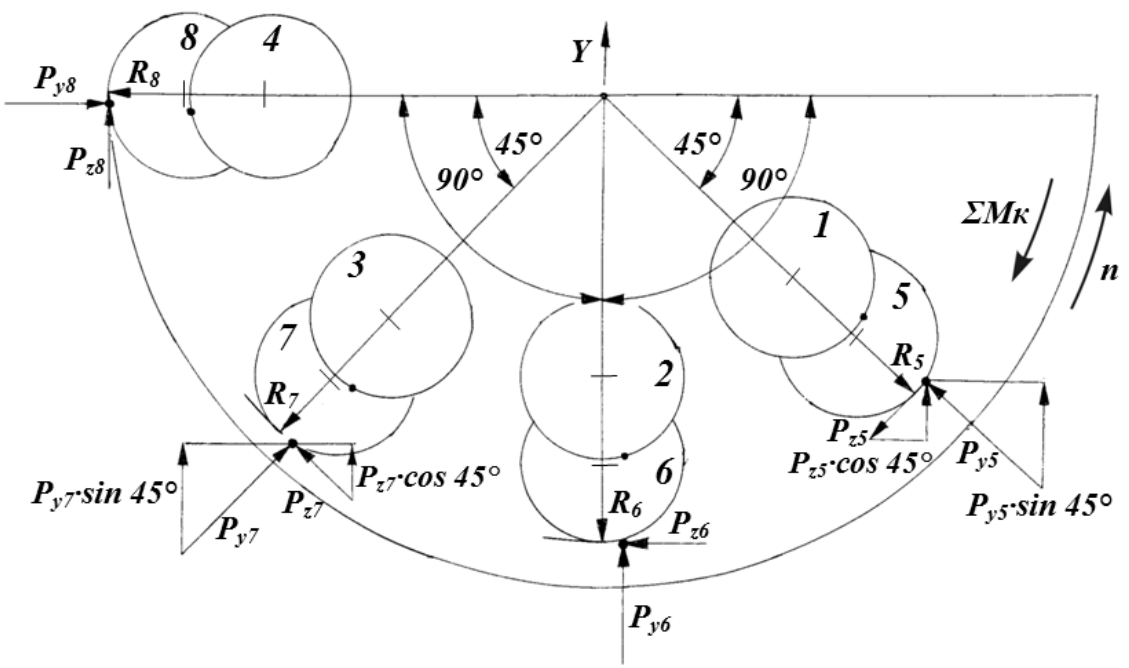

Fig. 5. The scheme of components of the efforts of rolling $\mathrm{P}_{\mathrm{z}}$ and the effort of impressing $\mathrm{P}_{\mathrm{y}}$ in the destruction of rock by disk tools (№ 5, 1, 6, 2, 7, 3, 8, 4) of the right crown at itsdownward motion

For the option of the downward motion of the right crown presented in Fig. 5, the calculated expressions are as follows:

$$
\begin{array}{llll}
\mathrm{P}_{\mathrm{o} 5}=\mathrm{P}_{\mathrm{y} 5} \sin 45^{\circ}+\mathrm{P}_{\mathrm{z} 5} \cos 45^{\circ} ; & \mathrm{P}_{\mathrm{o} 6}=\mathrm{P}_{\mathrm{y} 6} ; & \mathrm{P}_{\mathrm{o} 7}=\mathrm{P}_{\mathrm{y} 7} \sin 45^{\circ}+\mathrm{P}_{\mathrm{z} 7} \cos 45^{\circ} ; & \mathrm{P}_{\mathrm{o} 8}=\mathrm{P}_{\mathrm{z} 8} ; \\
\mathrm{P}_{\mathrm{o} 1}=\mathrm{P}_{\mathrm{y} 1} \sin 45^{\circ}+\mathrm{P}_{\mathrm{z} 1} \cos 45^{\circ} ; & \mathrm{P}_{\mathrm{o} 2}=\mathrm{P}_{\mathrm{y} 2} ; & \mathrm{P}_{\mathrm{o} 3}=\mathrm{P}_{\mathrm{y} 3} \sin 45^{\circ}+\mathrm{P}_{\mathrm{z} 3} \cos 45^{\circ} ; & \mathrm{P}_{\mathrm{o} 4}=\mathrm{P}_{\mathrm{z} 4}
\end{array}
$$

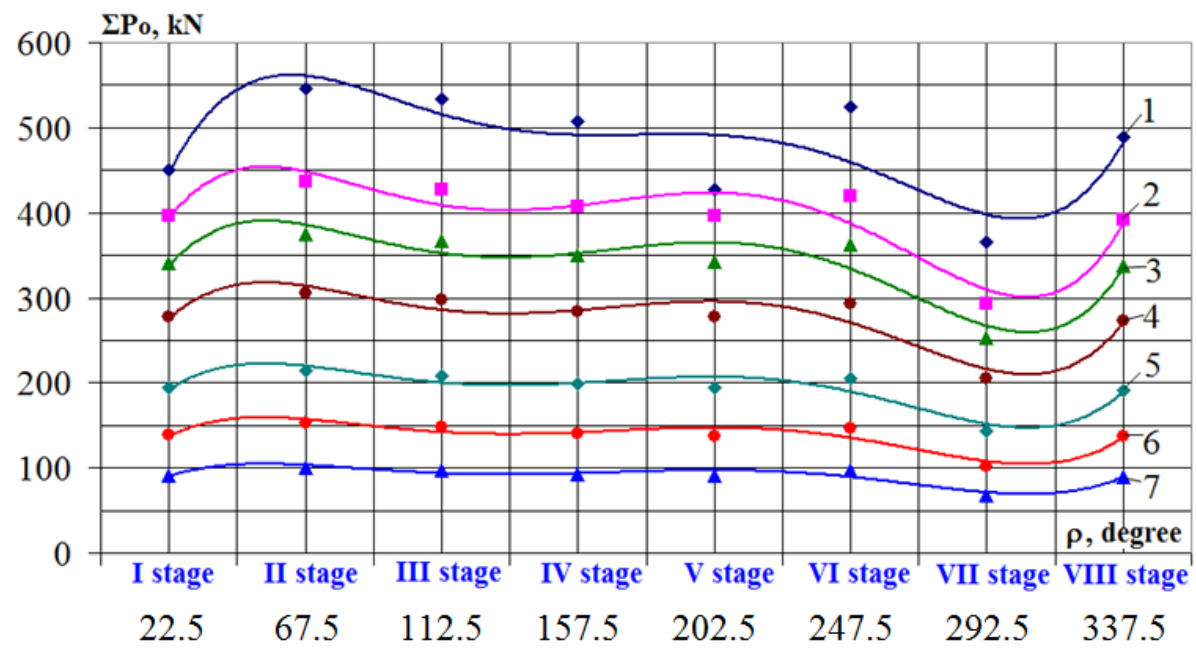

Fig. 6. Dependences of efforts $\Sigma$ Po from the angle of rotation $\rho$ of the left crown: $1-\mathrm{Pc}(1250 \mathrm{MPa}) ; 2-\mathrm{Pc}(1000 \mathrm{MPa})$ 3 - Pc (860 MPa); 4 - Pc (700 MPa); 5 - Pc (490 MPa); 6 - Pc (350 MPa); 7 - Pc (230 MPa)

The graphs presented in Fig. 6 are described by the following polynomial dependences:
$1-\sum \mathrm{P}_{\mathrm{o}}=0.9799 \rho^{5}-22.082 \rho^{4}+187.25 \rho^{3}-739.62 \rho^{2}+1323.6 \rho-303.88$;
$\mathrm{R}^{2}=0.6158$;
$2-\sum \mathrm{P}_{\mathrm{o}}=0.9662 \rho^{5}-21.061 \rho^{4}+170.08 \rho^{3}-628.13 \rho^{2}+1034.6 \rho-163.17$;
$\mathrm{R}^{2}=0.8185$;
$3-\sum \mathrm{P}_{\mathrm{o}}=0.8281 \rho^{5}-18.042 \rho^{4}+145.62 \rho^{3}-537.59 \rho^{2}+885.67 \rho-138.25$;
$\mathrm{R}^{2}=0.816$;
$4-\sum \mathrm{P}_{\mathrm{o}}=0.6787 \rho^{5}-14.802 \rho^{4}+119.6 \rho^{3}-441.86 \rho^{2}+727.68 \rho-115.95$;
$\mathrm{R}^{2}=0.8211$;
$5-\sum \mathrm{P}_{\mathrm{o}}=0.4751 \rho^{5}-10.361 \rho^{4}+83.72 \rho^{3}-309.31 \rho^{2}+509.39 \rho-81.169$;
$\mathrm{R}^{2}=0.8211$
$6-\sum \mathrm{P}_{\mathrm{o}}=0.3488 \rho^{5}-7.6188 \rho^{4}+61.64 \rho^{3}-227.84 \rho^{2}+374.69 \rho-63.548$;
$\mathrm{R}^{2}=0.816$
$7-\sum \mathrm{P}_{\mathrm{o}}=0.2279 \rho^{5}-4.9733 \rho^{4}+40.2 \rho^{3}-148.49 \rho^{2}+244.27 \rho-40.78$;
$\mathrm{R}^{2}=0.8113$ 
The calculations are made for boom-type cutting bodies of roadheaders, which use two-threaded schemes of a set of disk tools on two kinematically connected reverse radial crowns. The crowns contain the bodies of a truncated conical shape with the triangular prisms of the same length with the disk tool attachment assemblies forming the radial beams of various radii equal to radii of rolling of disks on a face with angular shift relative each other. This excludes contacting of disk tools of the left and right crowns between themselves in the central part of the face.

\section{CONCLUSION}

It is shown that the external efforts $\mathrm{P}_{\mathrm{o}}$ acting on the disk tools from the face depend on the following parameters: crown angle of rotation $\rho$, radius of a trajectory of rolling of disks R, efforts of rolling $\mathrm{P}_{\mathrm{z}}$, effort of impressing $\mathrm{P}_{\mathrm{y}}$.

It is defined that external efforts $\mathrm{P}_{\mathrm{o}}$ on single disk tools have the areas of increments from $\mathrm{P}_{\mathrm{o} \text { min }} 0.7-0.8 \mathrm{kN}$ to $\mathrm{P}_{\mathrm{o} \text { min }} 70.9$ $92.7 \mathrm{kN}$ and then the areas of falling from $\mathrm{P}_{\mathrm{o} \text { min }} 70.9-92.7 \mathrm{kN}$ to $\mathrm{P}_{\mathrm{o} \text { min }} 0.6-7.9 \mathrm{kN}$.

Recommended were the parameters of two-spiral schemes of disk tools arrangement on crowns (a rolling pitch, angular distance between the next disks, number of disks in the rolling line) which provide the change in the external loading $\Sigma \mathrm{P}_{\mathrm{o}}$ for one full turn of crowns not exceeding 26-37\%.

It was identified that with an increase in contact strength of rock $\mathrm{P}_{\mathrm{c}}$ from $230 \mathrm{MPa}$ to $1250 \mathrm{MPa}$, total effort $\Sigma \mathrm{Po}$ increases pro rata.

It is noted that during the upward operation of the crowns, $\Sigma \mathrm{P}_{\mathrm{o}}$ is less than during their downward operation by $10-15 \%$ which is explained by weakening of the rock mass $(\mathrm{k}=0.85-0.9)$.

It is established that the total external loading $\Sigma \mathrm{P}_{\mathrm{o}}$ on the right crown is $16-38 \%$ less than on the left crown as at $\rho=$ $0^{\circ}$ or $360^{\circ}$ due to mutual influence of disk tools on each other the rock in the face is broken in the zone between the crowns by the disks of the left crown, and the disks of the right crown don't engage with them. At the same time, on dependences $\Sigma P_{o}=f(\rho)$ its concavity is observed $(\rho=270$ $360^{\circ}$ ), and these dependences represent the family of polynoms of the fifth degree.

\section{ACKNOWLEDGEMENT}

The authors express their thanks and gratitude to the first deputy chief mechanical engineer on mining equipment in the company "SUEK-Kuzbass" Mukhortikov S.G., head of laboratory of underground robotics of the Federal research center of coal and coal chemistry, Siberian branch of the Russian Academy of Sciences, Ph. D., Aksenov V.V., head of department of metal cutting machines and instruments, professor, Ph. D. Korotkov A.N., professor of department of technology of machine-building, Ph. D., Blumenstein V.Yu., head of center of informatization, candidate of technical sciences, associate professor of department of mining equipment of Yurga technological institute (branch) of the Federal state autonomous educational establishment of higher education "National research Tomsk Polytechnic University" Vorobyov A.V. for their active, creative cooperation and support.

The research results are obtained within the framework of the state order of the Ministry of Education and Science of Russia, project 632 "Investigation of technologies and techniques parameters for selecting and developing innovative designs to improve operating efficiency of multipurpose mining machines in Kuzbass".

\section{REFERENCES}

[1] Khoreshok A. A. Mametyev L. E. Tshehin A. M. Nesterov V. I Borisov A. Yu. Osnovnye jetapy razrabotki i modelirovanija parametrov diskovogo instrumenta prohodcheskih i ochistnyh gornyh mashin [The main stages of development and modeling parameters of the disk tool roadheaders and shearers]. Gornoe oborudovanie i jelektromehanika. 2015. \#7. P. 9-16.

[2] Mametyev L. E. Khoreshok A. A. Tsekhin A. M. Borisov A. Yu. Distribution of stresses between the parts of the attachment points of the disk tools when drifting face destruction. Journal of Mining Science. 2015. Volume 51, Issue 6.

[3] Borisov A. Yu., Mametyev L. E. Naprjazhenija v soprjagaemyh jelementah diskovyh instrumentov pri razrushenii prohodcheskih zaboev [The stress in the mating elements of the disk tools in the destruction of the tunnel faces]. Vestnik kuzbasskogo gosudarstvennogo tehnicheskogo univeristeta [Vestnik of Kuzbass State Technical University]. 2015. \# 4. pp: 26-35.

[4] Buyalich G.D. Aleksandrov B.A., Antonov Yu.A., Voyevodin V.V. Increasing the resistance of powered support brackets J. Journal of Mining Science. 2000. Vol 36. \# 5. pp 487-492.

[5] Buyalich G.D., Buyalich K.G. Modeling of hydraulic power cylinder seal assembly operation, Mining 2014: Taishan academic forum Project on mine disaster prevention and control: Chinese coal in the century: mining, Green and safety, China, Qingdao, 17-20 October 2014. Amsterdam, Paris, Beijing. Atlantis Press, 2014. pp. 167-170.

[6] Buyalich G.D., Buyalich K.G, Voyevodin V.V. Radial deformations of working cylinder of hydraulic legs depending on their extension. IOP Conference Series: Materials Science and Engineering. 2015. T. 91. \# 1. p. 012087.

[7] Aksenov V.V., Khoreshok A.A., Ananyev K.A., Ermakov A.N. Opredelenie silovyh i kinematicheskih parametrov ispolnitel'nyh organov geohoda metodom imitacionnogo modelirovanija [Estimation of force and kinematic parameters of cutting drums of geokhod]. Vestnik kuzbasskogo gosudarstvennogo tehnicheskogo univeristeta [Vestnik of Kuzbass State Technical University]. 2016. \# 1. pp: 77-83.

[8] Antonov Y.A., Kovalev V.A., Nesterov V.I., Buyalich G.D. Sovershenstvovanie gidrosistemy prohodcheskogo kombajna [Improvement of hydraulic tunnel shearer]. Vestnik kuzbasskogo gosudarstvennogo tehnicheskogo univeristeta [Vestnik of Kuzbass State Technical University]. 2012. \# 4. pp: 11-13.

[9] Aksyonov V.V., Blashchuk M.Yu., Chernukhin R.V. Komponovochnye shemy jenergosilovoj ustanovki geohoda [Assembly schemes of geohod's power plant]. Vestnik kuzbasskogo gosudarstvennogo tehnicheskogo univeristeta [Vestnik of Kuzbass State Technical University]. 2014. \# 3. pp: 33-38.

[10] Aksenov V.V., Efremenkov A.B., Beglyakov V.Yu. The influence of relative distance between ledges on the stress-strain state of the rock at a face. Applied Mechanics and Materials. 2013. Volume 379. pp. 16-19.

[11] Aksenov V.V., Lavrikov S.V., Revuzhenko A.F. Numerical modeling of deformation processes in Rock Pillars. Applied Mechanics and Materials. 2014. Volume 682. pp. 202-205.

[12] Timofeev V.Y., Aksenov V.V., Galjamova J.I. Determination of parameters of roller of wave transmission with intermediate rolling bodies with hollow shaft for geokhod. Applied Mechanics and Materials. 2014. Volume 682. pp. 246-250. 
[13] Burkov P.V., Burkova S.P., Timofeev V.Y. Justifying a method of balancing crank-and-rod mechanism of mining roadheader. Applied Mechanics and Materials. 2014. Volume 682. pp. 270-275.

[14] Blashchuk M.Y., Kazantsev A.A., Chernukhin R.V. Capacity calculation of hydraulic motors in geokhod systems for justification of energy-power block parameters. Applied Mechanics and Materials. 2014. Volume 682. pp. 418-425.

[15] Begljakov V.Y., Timofeev V.Y., Dokhnenko M.V. Parameters of force Interaction of elements the wave transmission with Intermediate rolling bodies in geokhd's transmission. Applied Mechanics and Materials. 2014. Volume 682. pp. 282-287.

[16] Prokopenko S.A. Multiple service life extension of mining and road machines' cutters. Applied Mechanics and Materials. 2014. Volume 682. pp. 319-323.

[17] Xin Zhang, Ji Long Zhao, Qing Liang Zeng. Study of the testing system for roadheader pump and motor. Applied Mechanics and Materials. 2015. Volumes 727-728. pp. 761-764.

[18] Xiao Dong Wang, Ming Quan Shi, Shu Jun Gao. Yang Chen Guo. Design of transverse boom-type roadheader remote control system. Applied Mechanics and Materials. 2015. Volumes 701-702. pp. 679683.

[19] Bin Zhao, Xue Mei Zong, Bing He, Li Jie Zhang. Multi variable multi objective optimization for the cutting head of roadheader. Applied Mechanics and Materials. 2014. Volumes 635-637. pp. 358-364.

[20] Ye Fei, Wei Na Zhang, Zhe Hao Wu. Optimization of roadheader crawler parameters based on the theory of driving. Applied mechanics and materials. 2014. Volume 532. pp. 394-397.
[21] Zi Xian Yang, Xiao Dong Ji, Hai Jiang, Yu Long Hu, Miao Wu. Tes and research on vibration characteristics of EBH300(A) roadheader. Applied Mechanics and Materials. 2014. Volume 487. pp. 352-356.

[22] Xiao Huo Li, Wei Du, Zhi Long Huang, Wei Li Fu. Simulation of disc cutter loads based on ANSYS/LS-DYNA. Applied Mechanics and Materials. 2012. Volume 127. pp. 385-389.

[23] Zi Long Zhou, Xi Bing Li, Guo Yan Zhao, Zhi Xiang Liu, Guang Ju $\mathrm{Xu}$. Excavation of high-stressed hard rock with roadheader. Applied Mechanics and Materials. 2011. Volumes 52-54. pp. 905-908.

[24] Feng Hua Li, Zong Xi Cai, Yi Lan Kang. A theoretical model for estimating the wear of the disc cutter. Applied Mechanics and Materials. 2011. Volumes 90-93. pp. 2232-2236.

[25] Zhi Feng Dong, Li Yu Fang, Gong Dan, Chuan Feng Deng. The modal analysis with finite element method for body section of EBZ160 roadheader. Advanced Materials Research. 2014. Volumes 945-949. pp. 1207-1210.

[26] Man Man Xu, Yu Li, Sai Nan Xie, Qing Hua Chen. Finite element analysis on rack and pinion of roadheader. Advanced Materials Research. 2013. Volumes 791-793, pp. 718-721.

[27] Li Juan Zhao, Xiu Mei Lv, Wei Tong. Research on boom-type roadheader vibration testing based on the LabVIEW. Advanced Materials Research. 2012. Volumes 418-420. pp. 1988-1991. 